\title{
Supply chain bottlenecks in the South African construction industry: Qualitative insights
}

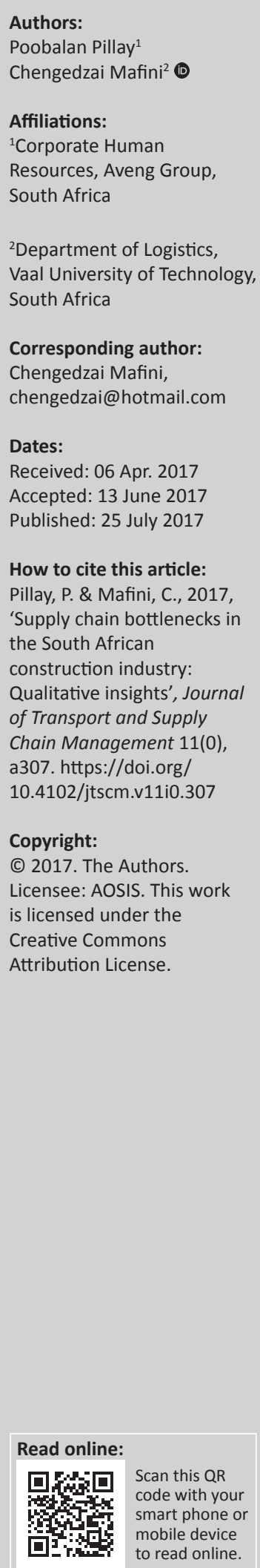

Background: The construction industry in South Africa has a lot of potential but its performance is still restricted by numerous internal and external challenges. Unless these challenges are identified and understood better, further growth of this industry is likely to be hindered, which has negative economic implications for the South African economy.

Objectives: This study investigated supply chain bottlenecks faced by the construction industry in South Africa. It also discussed solutions for addressing the identified bottlenecks in order to facilitate the continued development of supply chain management in the construction industry.

Method: The study used a qualitative approach in which in-depth interviews were held with purposively selected senior managers drawn from the construction industry in South Africa. Content analysis using ATLAS.ti software was employed to identify the themes from the collected data.

Findings: The findings of the study showed that supply chain management in the construction industry in South Africa is constrained by five major bottlenecks: skills and qualifications, procurement practices and systems, supply chain integration, supply chain relationships and the structure of the construction industry. Recommendations for addressing each of these five challenges were put forward.

Conclusion: The study concludes that both awareness and application of supply chain management in the construction industry in South Africa remains inhibited, which creates opportunities for further improvements in this area to realise the full potential of the industry.

\section{Introduction and background}

In South Africa, the construction Industry is one of the principal contributors to the country's economy. As reported by Statistics South Africa (2016), the construction industry contributes a significant percentage of the gross domestic product (GDP) and provides employment to a substantial proportion of the working population in the country. According to the Construction Industry Development Board (2016), the construction industry in South Africa makes up at least $50 \%$ of the total national capital investment in the country and as much as $4 \%$ of the GDP. Statistics South Africa (2014) estimates that the total income for the construction industry was R15.68 billion in 2012, R16.48bn in 2013 and R15.42bn in 2014. In 2015, it was anticipated that the output value of the South African construction industry would rise at an annual growth rate of $2.62 \%$ by the year 2020 (Report Buyer 2016). The major driver for the expansion of the construction industry in South Africa is government spending on infrastructure. For instance, to develop the country's transport, water and energy infrastructure, the government announced plans in its 2015 budget to spend R813.1bn on infrastructure until the year 2019 (Nene 2015). The government further planned to construct up to 1.5 million houses by 2019 as part of the Human Settlements Vision 2030, and to replace at least 510 mud-school buildings across the country by 2023 (Report Buyer 2016). Such massive spending on infrastructure by the government, coupled with similar efforts by private investors, serve as indicators of the encouraging prospects facing the construction industry in South Africa.

The economic environment in South Africa is currently riddled with myriad pressures that threaten the viability of most businesses across different industries. For instance, international competition, especially from China, remains a major threat, because the latter is able to offer products and services on a very cost-competitive basis (South African Federation of Civil Engineering Contractors 2014). The emphasis placed on black economic empowerment policies by government has also stimulated the mushrooming of numerous black-owned businesses. Most government 
contracts are awarded to these black-owned businesses, despite the scepticism surrounding their ability to produce quality products and services (PricewaterhouseCoopers 2017). Most black-owned businesses in South Africa, which are linked to black-owned empowerment policies, have struggled to produce quality outputs, leading to a general view that awarding contracts to them is tantamount to wastage of resources (Motsetse 2015). Recent trends are also showing a reduction in qualified skills in South Africa. For instance, the Department of Higher Education and Training (2016) produced a List of Occupations in High Demand 2015, which showcases numerous professions (over 150) where there are shortages of personnel in South Africa. The Engineering Council of South Africa (2015) likewise noted that the number of professional engineers in the country has declined in recent years. Furthermore, as noted by Mafini and Dhurup (2015), even where clients are satisfied with the quality of the delivered product, they are often dissatisfied with the level of the quality of professional services offered by many firms operating in various South African industries. Still, the operating environment in the country is highly unstable and volatile, characterised by discontinuities and fluctuations in demand (Mafini, Loury-Okoumba \& Pooe 2016). Moreover, corruption, fraudulent practices and the inability to adopt best practices remain unrestrained threats to most industries, leading to high operating costs in South Africa (Bowen, Pearl \& Akintoye 2007). These threats appear to be generic across most industries in South Africa.

To deal with the above challenges, industries, including construction, are compelled to either develop or embrace more effective business best practices in order to remain competitive. It is without doubt that supply chain management is among the emergent business practices that have revolutionised the way business is conducted. Supply chain management refers to the administration of information flows, activities, tasks and processes, involving various networks of independent organisations and linkages (upstream and downstream), which produce value that is delivered to the owner in the form of a finished project (Van Weele 2014). In the modern world, competition is no longer between individual business enterprises, but between supply chains. Supply chain management practices are useful for efficiently integrating suppliers, manufacturers, warehouses and other intermediate value-adding partners to ensure that production and distribution are synchronised with customer demand, thereby reducing the overall system or pipeline costs and satisfying service-level requirements (Esper Defee \& Mentzer 2010; Hugo, Badenhorst-Weiss \& Van Bilton 2004). Van Weele (2014) recognises that supply chain management has become a fundamental concern for many organisations as it provides the prospect of making significant cost savings and improving value by enabling firms to work more effectively together across the entire supply chain. Its main goal is to reach solutions with optimised profit for all supply chain partners (Kozlenkova et al. 2015; Wieland \& Handfield 2013). However, there is often a great disparity between potential benefits and the practice, because there are several bottlenecks or constraints in supply chains that have to be resolved through efficient and effective business practices (Simatupang \& Sridharan 2012). Examples of these bottlenecks include limitations in intellectual capital, the lack of financial resources, inadequate production capacities resulting from equipment-related problems, unfavourable policies, dysfunctional organisational cultures and politics, obsolete technology and the ineffective management of resources, among others (Linhares 2009; Stevenson 2012). It is therefore essential to investigate these bottlenecks continuously with a view to streamline supply chain management activities in various economic sectors, including the construction industry in South Africa.

Within the context of the South African construction industry, supply chain management involves integrating the operations of all organisations involved with the successful completion of a specific construction project (Bowen et al. 2007). As suggested by Shakantu et al. (2007), supply chain partners in the construction industry tend to act as an identical entity, which ensures that profits and performance are enhanced throughout the supply chain. However, as observed in a study by Emuze and Smallwood (2013), the present needs of the market in the South African construction industry have made supply chain processes increasingly complex. In particular, the industry is characterised by fluctuating demand, especially when related to achieving a competitive advantage. Additionally, supply chain partners have not been achieving the gains related to profitability and efficiency. This is because each business tends to consider and prioritise its own local bottlenecks, when in fact it should be holistically considering all global constraints related to supply chain management (Smallwood \& Emuze 2012). The ideal scenario would be that both the design and analysis of the supply chain as a whole are considered to be critical in the development of an efficient supply chain management system (Alves \& Tsao 2007). In view of this, continued discourse and research on the management of the increasingly complex construction supply chain in South Africa are necessary in order to keep abreast with developments.

\section{Problem statement}

Against the above backdrop, this study had the aim of investigating supply chain bottlenecks facing the construction industry in South Africa. The study further aimed to propose some practical solutions for addressing these bottlenecks in order to facilitate the continued development of the supply chain management function in the construction industry. As mentioned before, the construction industry performs a major role in the South African economy, contributing in such areas as employment creation, investment and infrastructural development, among others. Be that as it may, the outputs from that industry portray a depressed picture. For instance, in his report as the then Minister of Public Enterprises, Gigaba (2014) pointed to the prevalence of issues such as anticompetitive behaviours (e.g. cartels), poor quality outputs, delays in payment, frequent spells of labour unrest and customer and/or client dissatisfaction, that are symptomatic of the general underperformance of the construction 
industry in South Africa. A report by PricewaterhouseCoopers (2014) attributed the expansion of South African construction firms into new markets in Africa to the need to improve profits in the wake of environmental threats at home. Another report on the status of the construction industry highlights that only about half of the projects are delivered on schedule, within the budget and relatively defect free and that there is low customer satisfaction with the performance of contractors and consulting professionals (Construction Industry Development Board 2016). This validates the view that the construction industry in South Africa has to contend with certain counterproductive forces that tend to constrain its performance. Unless counteractive measures are found, the downward trajectory in performance is bound to continue and could lead to the demise of the industry, with obvious repercussions for the South African macro-economic landscape. Remedial measures to this situation cannot be created on the basis of unfounded claims or speculation, but on the basis of an authentic understanding of the driving forces behind such problems. Hence, this study was intended to investigate bottlenecks facing the construction industry, which opens avenues for finding lasting solutions to the performance issues facing the industry.

In addition, there is a manifest need to expand supply chain management research to the construction industry in South Africa. It appears that supply chain management research in the construction industries within developing countries such as South Africa should be developed further, because some research gaps still remain, thereby presenting opportunities for further studies in this area. For example, an Internet database search for previous supply chain management research in the South African construction industry found limited evidence. The most notable research evidence is from three studies. The first study was conducted by Emuze and Smallwood (2013), which focused on approaches to enhance the proliferation of supply chain management in this industry. The second study was conducted by Antony (2013) and directed its attention to the legal regulation of construction procurement in South Africa. The third study was conducted by Ibem and Laryea (2015) and concentrated on the use of e-procurement in the same industry. Besides these three studies, much of the available research was conducted in non-African economies (e.g. Bankvall et al. 2010; Dainty, Millett \& Briscoe 2001; Eriksson 2010; Gohari 2014; Hyll 2005; Khalfan, McDermott \& Cooper 2004; Ojo, Mbowa \& Akinlabi 2014; Nordin et al. 2010; Olson 2000; Segerstedt \& Olofsson 2010; Vrijhoef \& Koskela 2000). However, with the exception of Ojo et al. (2014), none of these previous studies, directed their primary spotlight to supply chain bottlenecks facing the construction industries they were examining. This lack of research evidence is surprising, given the view by Zaghoul and Hartman (2013) that the management and control of factors influencing the success of supply chains remains a principal activity for achieving greater performance in the construction industry. The presence of these research gaps presented the need for this study to contribute to the literature on supply chain management within the context of the South African construction industry. Accordingly, this study concentrated on specifying the bottlenecks prevalent in the same industry, with the intent to provide theoretical insights relevant to the construction industry in developing countries.

The remainder of this article is organised as follows: the next section discusses the literature on the construction industry in South Africa and supply chain management in the construction industry. Thereafter, the article presents the research method in terms of the research approach, participants, measures of trustworthiness and data analysis. This is succeeded by a discussion of the findings and limitations of the study as well as the suggestions for further research. The final section of the article presents the conclusions and recommendations.

\section{Theoretical overview}

The theoretical overview provides brief insights on the construction industry in South Africa and supply chain management in the construction industry.

\section{The construction industry in South Africa}

Generally, the construction industry is that sector of the economy which is responsible for the planning, design, construction, maintenance and eventual demolition of buildings and the common infrastructure (Chun, Hwang \& Byun 2015; Doloi 2013). It encompasses all civil engineering work and all types of new building projects (including housing), as well as the maintenance and repair of existing facilities (Khalfan, McDermott \& Swan 2007; Lönngren, Rosenkranz \& Kolbe 2010). As a service industry, construction obtains its inputs and outputs from various sectors of the economy with which it is interrelated and interlinked, often in quite complex ways (Voordijk, Meijboom \& De Haan 2006). The importance of construction derives from its role in the generation of constructed physical facilities and in employment, which, in turn, play a critical and highly visible role in the development of a country (Arantes, Ferreira \& Costa 2015). In South Africa, approximately $50 \%$ of the total construction output is directed to civil engineering projects such as transport facilities, power projects, irrigation, drainage and water supplies, among others (Construction Industry Development Board 2016). Housing generally makes up less than $25 \%$ of the total output and the remainder is in other buildings such as hospitals, schools, offices, factories, hotels and agricultural buildings (Construction Industry Development Board 2011). In terms of composition, at least $78 \%$ of construction firms are composed of small- and medium-scale contractors (Rust et al. 2013). This composition is out of sync with government initiatives because the percentage spent on economic infrastructure is targeted at large construction firms, yet the industry is dominated by small and medium enterprises.

The construction industry in South Africa faces a number of challenges that are well documented in literature. For instance, because of global economic dynamics, essential 
resources such as skilled manpower, financial capital, the latest technology and intellectual capital are scarce in South Africa, which makes the construction industry unstable and volatile, being characterised by discontinuities and fluctuations in construction demand (Rust et al. 2013). It is for these reasons that most local contractors are neither able to maintain and develop permanent supervisory staff and skilled labour nor establish an appropriate supply of basic equipment (Ofori 2013). It is also acknowledged that because there is a shortage of skilled labour in South Africa, most construction activities in the country tend to depend mostly on unskilled labour, leading to the compromised quality of outputs (Windapo 2016). A study conducted by Khumalo, Mashiane and Roberts (2014), which examined construction projects in South African firms, established that by the time a project is complete, the actual cost exceeds the original contract price by $30 \%$ while change orders result in a $8.3 \%$ cost overrun. As a result, firms struggle to remain profitable and may resort to unethical practices such as cartels and collusion in order to survive. Additionally, Modares and Sepehri (2009) report that corruption, fraudulent practices and the inability to adopt best practices continue to hamper construction activities in South Africa. Smallwood and Emuze (2012) add that small contractors face difficulties in obtaining credit to procure essential plant and equipment, as there is no continuity of work and no assurance of jobs. As a result, they are often trapped in a sequence of inefficient technology, leading to low productivity. Government influence in the construction industry is also high and is felt through policies and legislation regarding licenses and permits, sanitary and building codes, minimum wage rates, corporate taxes, rules on importation of materials and terms and availability of financing for construction (South African Construction Industry Status Report 2013). Also prevalent is the impact of the informal sector on the construction industry, as numerous unregulated and unprotected individuals and enterprises engage in economic activities in construction (Mbande 2010). The result of the activities of these informal players include low quality of construction outputs, instability, resistance to progress and change and a considerable inertia in using modern materials and techniques (Esser \& Decker 2008).

\section{Supply chain management in the construction industry}

The construction supply chain is simply a network of firms that agreed to work together in order to realise objectives relative to construction projects (Beer \& Noria 2000; Eddie et al. 2001). The application of supply chain management to the construction industry only began after the turn of the 21st century because the concept was previously concentrated in a handful of industry sectors such as consumer good retailing, computer assembling and manufacturing (Albaloushi \& Skitmore 2008). However, as the concept became more popular, it was embraced in other industries such as real estate, education, recreation, health to tangible aspects of construction, business services, finance, mining, agriculture forestry and fisheries and many more (Gilgor \& Holcomb 2012; Peat \& Anna 2007). Since its adoption in the construction industry, there are a number of supply chain management best practices that have dominated the industry. These include a commitment towards sustainable relationships between contractors, suppliers and distributors (Titus \& Bröchner 2005); elimination of waste through lean construction (Titus \& Bröchner 2005); procurement (Venkataraman \& Pinto 2008); process improvement (Emuze 2009); and technology that fosters the environment for best practice operations (Sohail \& Cavill 2008). Other supply chain management practices that have a bearing on construction projects include logistics (Perera, Avis \& Marosszeky 2009) and inventory management (Shakantu et al. 2007). Through implementation of these practices, various benefits have been realised, such as improved relationships between supply chain partners, reduced operational costs, improved inventory management, superior supplier performance, better quality outputs, enhanced customer satisfaction and higher profits for businesses (Eriksson 2010; Gohari 2014). $\mathrm{Wu}$ and Weng (2010) add that because cost, flexibility, quality and time are drivers of supply chain management, their performance provides a barometer for successfully measuring the performance of a construction supply chain. Thus, supply chain management practices have a wide spectrum of application within the construction industry.

\section{Methodology}

The methodology section briefly discusses the research approach, participants and data collection, trustworthiness and data analysis.

\section{Research approach}

The aim of this study was to investigate supply chain management bottlenecks in the South African construction industry. A qualitative study was adopted to facilitate the achievement of this aim through the collection of in-depth data. The choice of the research approach was influenced by the fact that no previous study that specifically targeted supply chain management bottlenecks in the construction industry in South Africa was found. As put across by Creswell and Poth (2013), qualitative studies are most applicable in under-researched environments. The construction industry in South Africa satisfies this condition because supply chain management research in general is still at a low scale within this industry. Besides, the use of qualitative approaches enables direct interaction with the participants, which further allows for probing, thereby providing them with opportunities to respond in their own words, rather than compelling them to select from fixed responses as is done in quantitative studies (Padgett 2016). Through the application of in-depth interviews, the study intended to obtain the views of participants regarding which factors were limiting the effective implementation of supply chain management in the construction industry and what measures could be taken to deal with these factors. 


\section{Data collection and participants}

In the present study, primary data were collected through semi-structured in-depth interviews held between February and April 2016. Interviews were held at designated sites in various provinces after informed consents and permissions had been obtained from the key stakeholders. Each interview was held in English language, ran for between 20 and 30 min and was recorded using a digital voice recorder, in line with the prescription by Lee and Lings (2008). In addition, notes were actively taken during the interviews and participants were given opportunities to comment on any issues under discussion. Participants were not given any incentive for participating in the interviews. Interviews were conducted until data saturation, where additional interviews no longer produced more information because the views being put forward by participants were nearly the same at this stage (Mason 2010).

A non-probability purposive sampling technique (Cresswell \& Plano Clark 2011) was employed to improve sample representativeness. The participants in this research were 15 senior managers drawn from firms operating within the construction industry in South Africa. The participants sampled had a long and credible construction industry experience (at least 10 years) particularly in supply chain management. The demographic description of the participants is provided in Table 1.

Table 1 shows a summary of the demographic details of the participants. Of the 15 participants, 10 were men while 5 were women, showing that both genders were represented in the sample. The age groups show that all respondents were aged between 36 and 63 . In terms of racial profile, the seven participants were black people, three were white people, four were Indian and one was of the mixed race, which demonstrates that there was a racial representativeness in the study. The occupations of the participants show that all of them were occupied in positions falling under supply chain management. The work experience of participants ranged between 11 and 27 years. Gauteng was the province with the largest number of participants (four in total), followed by Eastern Cape, Limpopo, Mpumalanga and Western Cape, all of which were represented by two participants. However, KwaZulu-Natal, North-West and the Free State had one participant each. The number of participants per province was determined by the willingness of approached individuals to participate in the study. Hence, no one from the Northern Cape volunteered to participate in the study.

\section{Trustworthiness}

During the course of the research study, credibility, dependability, confirmability and transferability were maintained. According to Finfgeld-Connett (2010) a credible study is one which manages to produce believable findings. In this study, credibility was established through the use of a purposive sample, which ensured that only those individuals who possessed information that was related to the aim of this study were recruited as participants. Credibility was also enhanced by securing informed consent from the participants, which ensured that the latter gave their best responses. Confirmability refers to the extent to which the inferences of a research study may be independently supported by others (Lincoln, Lynham \& Guba 2011). To establish confirmability, an audit trail was completed for all interviews by ensuring that participants were given the chance to go through their individual interview transcripts. All participants confirmed that that the interviews had been captured accurately.

Transferability refers to the degree to which the findings of a study can justifiably be generalised to any other context (Saldaña 2011). To ensure transferability in this study, the construction industry in various South African provinces was compared and determined to be similar, thereby proving that the findings of this study were applicable country-wide. Dependability may be perceived as the level of consistency of the findings (Corbin \& Strauss 2008).

TABLE 1: Demographic profile of participants.

\begin{tabular}{|c|c|c|c|c|c|c|}
\hline Participant code & Gender & Age & Race & Position occupied & $\begin{array}{l}\text { Years of experience in } \\
\text { construction industry }\end{array}$ & Province \\
\hline P1 & $M$ & 46 & Black & Logistics manager & 14 & Gauteng \\
\hline P2 & $M$ & 43 & Black & Procurement analyst & 12 & Kwa Zulu-Natal \\
\hline P3 & $\mathrm{F}$ & 38 & Black & Commodity manager & 13 & North-West \\
\hline P4 & M & 35 & Indian & Senior buyer & 10 & Western Cape \\
\hline P5 & $M$ & 55 & White & Head of procurement & 14 & Gauteng \\
\hline P6 & $\mathrm{F}$ & 36 & Black & Procurement analyst & 12 & Mpumalanga \\
\hline P7 & $\mathrm{F}$ & 39 & Black & Regional buyer & 12 & Eastern Cape \\
\hline P8 & M & 52 & Mixed & Chief procurement officer & 23 & Gauteng \\
\hline P9 & $\mathrm{F}$ & 39 & Indian & Commodity manager & 12 & Eastern Cape \\
\hline P10 & M & 51 & White & Chief procurement officer & 27 & Limpopo \\
\hline P11 & $M$ & 44 & Black & Operations manager & 16 & Limpopo \\
\hline P12 & M & 49 & Indian & Head of procurement & 15 & Western Cape \\
\hline P13 & M & 47 & Indian & Head of sourcing & 19 & Free State \\
\hline P14 & $\mathrm{F}$ & 37 & Black & Senior buyer & 11 & Gauteng \\
\hline P15 & $M$ & 63 & White & Plant and assets executive & 22 & Mpumalanga \\
\hline
\end{tabular}

$n=15$

$\mathrm{M}$, male; F, female. 
To ensure dependability of the findings, the triangulation approach was followed. Triangulation itself is the collection of data from different sources in order to obtain more wide-ranging or holistic findings (Jansen 2010). In this study, triangulation and hence dependability were established by collecting data from a wide array of secondary data sources and conducting interviews with diverse people drawn from different firms within the construction industry.

\section{Data analysis}

The collected data were transcribed from the voice format to word format in order to produce full-script written versions of each interview. The services of a professional transcriber were utilised in this instance (Schreier 2012). The resulting transcripts were carefully reviewed to verify whether the contents were in line with the recordings. The actual analysis of data was conducted with the aid of ATLAS.ti (version 7) software. ATLAS.ti is a workbench for qualitative data analysis, particularly for large sections of text, visual and audio data that is largely relevant to this form of study (Paulus \& Lester 2016). In using this software, a three-step process suggested by Sinkovics and Alfoldi (2012) was followed. The first step was to identify the categories of analysis and development of the coding system. This involved determining the appropriate unit or level of analysis (all answers, sentences or words that had been captured during data collection) and identifying the recurrent categories that gave meaning to the data. At the end of the process, a checklist that identified all the relevant categories, providing clear definitions and concrete examples in the data of each category was produced. This checklist was accompanied with rigorous instructions of how the data should be coded. The second step involved coding the data into the categories of analysis. This step involved the organisation and coding of all data in a way that ensured reliability and meaningfulness, that is, the previously defined categories (codes) were used to classify the content into explicative categories. Once all the data had been organised and coded, words, events or phrases that appeared similar were grouped into their identical categories or themes. This procedure was repeated until a point of saturation was reached, which is the point at which the themes began to appear repeatedly, indicating that no further analyses were necessary (Mason 2010). The extracted themes were the main findings of the study.

\section{Findings}

For the purpose of presentation and analysis, five key themes were identified and subsequently presented in this study (Table 2). These five themes were developed systematically through the application of the content analysis procedure. This procedure involved the examination of words and phrases from the collected data in order to provide interpretations that were contextualised to the construction industry in South Africa.
TABLE 2: Themes and their operational definitions.

\begin{tabular}{ll}
\hline Theme & Operational definition \\
\hline $\begin{array}{l}\text { Skills and qualifications } \\
\text { Procurement practices } \\
\text { and systems }\end{array}$ & $\begin{array}{l}\text { These refer to the competencies of employees } \\
\text { These are activities and processes related to the finding, } \\
\text { acquisition and purchase of goods and services from } \\
\text { external sources }\end{array}$ \\
Supply chain integration & $\begin{array}{l}\text { This refers to the management of a supply chain as one } \\
\text { entity through a close alignment and coordination of } \\
\text { activities }\end{array}$ \\
$\begin{array}{l}\text { Supply chain } \\
\text { relationships }\end{array}$ & $\begin{array}{l}\text { This refers to the manner in which firms in a supply } \\
\text { chain collaborate with each other }\end{array}$ \\
Structure of the industry & $\begin{array}{l}\text { This refers to the arrangement or organisation of the } \\
\text { industry in terms of number and size of firms in the } \\
\text { industry and how they compete with each other }\end{array}$ \\
\hline
\end{tabular}

\section{Theme 1: Skills and qualifications}

Participants lamented the lack of training and the resulting poor skills levels in the construction industry. It appears that no training programmes are in place to up-skill supply chain management professionals. This implies that these professionals in the construction industry may neither realise nor recognise the swift changes taking place in supply chain management because they lack necessary skills. These views are echoed through the following comment made by one of the procurement analysts (for all excerpts, participant details are provided in Table 1 ):

There is no training and development in this industry. Most of the supply chain staff are poorly educated, and so do not qualify for higher education unless they are able to secure entrance by virtue of age or experience. Most of them do not even request further training. (P2, Male, 46 years)

A senior buyer added a similar sentiment with regard to the level of training in the construction industry:

No one in supply chain receives training, but more importantly I do not believe that the existing operational buyers realise that they require training as they believe they are world class. (P4, Male, 35 years)

A head of procurement from a leading construction firm commented on the qualifications held by buyers:

Buyers in the organisation are mainly historic and therefore do not have the right qualifications and competencies. I had all the buyers undergo a competency test two years ago and results were shocking. Most of the buyers would fail a basic buying course. (P12, Male, 49 years)

Most of the participants confirmed that supply chain management training and development was not part of the culture in the construction industry. One of the procurement officers noted that because some of the lower level employees lacked the necessary skills, they were unable to challenge questionable decisions made by those in higher positions. As a result of the lack of skills, the same people constantly rotate from one firm to the next, continuing to maintain the same processes and culture. It is consequently not surprising that similar problems exist in the sector.

Similar to other industries, the study demonstrated the critical nature of the skills and qualifications-related bottlenecks within the construction industry in South Africa. As concluded by some scholars (Arantes et al. 2015; Lönngren 
et al. 2010; Tennant \& Fernie 2014), the tendency to disregard developments in supply chain management is endemic in the construction industry and could result in poor overall knowledge and skills. A report by PricewaterhouseCoopers (2014) further indicates that most executives in the construction industry are concerned about the availability of skilled professionals in the market. Emuze and Smallwood (2013) add that the demand for supply chain professionals is ever increasing in emerging markets such as South Africa as the realisation of the strategic nature of supply chain management continues to gain momentum. Construction and facilities-based commodity experience is in high demand, creating a need for strong skills in managing complex contracts for large buildings and engagement with thirdparty construction businesses (Aloini et al. 2012). Properly qualified personnel such as quantity surveyors, architects, estimators, contracts managers, engineers, demand planners and other supply chain professionals remain in high demand (Windapo 2016). Perhaps, this explains why there is stiff competition for the same skilled employees within the South African construction industry and why the execution of critical construction and supply chain management issues remains narrow. It is unfortunate that employers are not investing in recruiting and training candidates with the appropriate background skills and experience. This speaks to a potential limitation on the execution of the key supply chain-based and construction-based issues in general.

\section{Theme 2: Procurement practices and systems}

The responses of the participants suggest that there are serious constraints within the construction industry in terms of the proper streamlining of procurement practices and systems. The major issues that dominated the conversation included the relegation of buyers to the acquisition of lowvalue items and the lack of effective procurement systems. The following excerpt from one of the regional buyers reflects the ineffectiveness of procurement practices and systems in the construction industry:

Buyers are administrative in that their ability to make procurement decisions is restricted and on average they make decisions on possibly only 20 percent of all procurement spend. (P7, Female, 39 years)

A head of sourcing provided the case of his firm, where unfavourable decisions had been made without due respect to the buying function:

Some time ago, management in this firm chose to move the responsibilities of the buying function back to the respective managing directors of the business unit. This is counterproductive, as it makes it impossible for the chief procurement officer to control procurement activities. (P13, Male, 47 years)

Similarly, one of the commodity managers referred to the scenario in her firm, where the responsibilities of buyers had been kept within limited bounds:

In this firm, buyers can do paperwork and capture orders, but they are not allowed to negotiate with suppliers because management believes that as buyers, they do not have adequate information. As a result, as managers we have to do it ourselves. (P3, Female, 38 years)

In addition to the above, some of the participants mentioned that procurement in the construction industry is implemented ineffectively. For instance, a logistics manager indicated that their supply chain management division has up to eight procurement systems running in parallel. As a result, his firm experiences challenges stemming from clashes between the numerous systems and reporting spend data. Also notable was the view that supplier maintenance is a major challenge and previous spend records are usually neglected. The neglect of previous spend records signals that during procurement planning, very little, if any, reference is made to how funds allocated for procurement in the previous years were expended. Instead, funds are allocated to current procurement needs without considering the effectiveness or lack thereof, of past procurement practices as reflected through available historical records. These malpractices negatively affect future spending patterns within the industry because it becomes difficult to determine future allocations of procurement spend, even for basic materials such as cement and concrete.

The findings of the study revealed the entrenchment of a lacklustre approach to procurement in the construction industry. The downgrading of buyers to the acquisition of non-essentials coupled with the taking over of the same function by top managers suggests that the latter seem to have vested interests in the procurement function. As mentioned by Emuze and Smallwood (2013), when considered in the context of global advancements in procurement practices and systems, the construction industry in South Africa tends to be approximately $12-15$ years behind its international counterparts and is still fixated in a tactical procurement mentality, while the world is progressing towards strategic sourcing. This perhaps explains why the responsibility of buyers has been relegated to peripheral acquisitions with senior managers scrambling for all higher value acquisitions. Pryke (2009) highlights that such a scenario creates risk and could lead to opportunities for fraud and corruption, given that the actions and interests of senior managers are questionable. Furthermore, when buyers are undermined, as is the current situation in the construction industry, their capacity and continued development are both restrained, leading to their possible frustration and higher intentions to quit (Tran et al. 2011). A study by Ibem and Laryea (2015) concluded that adoption of state-of-the-art procurement systems within the construction industry in South Africa is at a fairly low level when compared to other industries and will require paradigm shifts in management support, skills, processes and systems to move towards best practice. Such ineffective utilisation of procurement systems could lead to inadequate information sharing within and between firms, inefficient decision making, increase of costs and reduced productivity (Moe \& Päivärinta 2013). It is thus apparent that structured supply chain management is non-existent in the South African construction industry and that procurement 
activities are mainly focused on buying activities, which seem to be mostly reactive and administrative.

\section{Supply chain integration}

Just as important as skills, qualifications and procurement practices and systems are to the success of the construction industry is the integration of various components of the construction supply chain. This is evident in the application of concurrent construction principles leading to project supply chain integration, which in turn improves value, eliminates inefficiencies and reduces project costs (Khalfan \& McDermott 2006). Participants revealed that supply chain integration is lacking in the construction industry. They indicated that there was a lack of strategic approach in trying to integrate the supply chain and that there were limited efforts to move either closer to suppliers or to merge with competitors. These concerns are rooted in the following excerpt from one of the heads of procurement:

Our activities are very disjointed, do not support supply chain activities and there is no attention being paid to implement a system which truly and effectively controls and integrates supply chain activities, either vertically or horizontally. (P5, Male, 55 years)

One of the chief procurement officers further alluded to the lack of a strategic mechanism for addressing supply chain management programmes:

There is no real strategic approach to supply chain integration that I can see. It is all done on a provisional basis and is driven by a program which in itself could be a plan I suppose - which is good. I'm not aware of any supply chain professionals in this firm who are applying their minds to the supply chain. (P10, Male, 51 years)

The construction industry is different from manufacturing because most contractors are not producers of assimilated end products. Most construction processes are non-repetitive and often result in high levels of waste (Vrijhoef \& Ridder 2003). As a result, low levels of coordination and invariability in development may lead to various challenges and underperformance of the construction supply chain (Shunmugam \& Rwelamila 2014). Resolving this calls for better arrangements and more organised methods for working in construction supply chains. Supply chain integration is a common approach for resolving supply chain coordination issues within and between supply chains (Fayazbakhsh, Sepehri \& Razzazi 2013). It is the close alignment and coordination of processes within the supply chain to produce a supply network that can enable all players to respond to market dynamics and reduce costs (Barnes \& Liao 2012). Through supply chain integration, organisations in supply chain become interlinked, working in unison. While it may be challenging to completely coordinate a supply chain network because of the temporary nature of construction projects, a sincere effort should be made to generate better results by integrating construction processes (Prajogo \& Olhager 2012). For instance, the construction industry could benefit from the integration of logistics functions and reverse logistics that have proved to be effective tools to improve transport utility in other industries such as manufacturing (McDermott \& Khalfan 2012). Accordingly, it is essential for the construction industry in South Africa to continue making strides towards the more intensive integration of the supply chain as a means to supporting, sustaining and consolidating its capacity and competing internationally.

\section{Supply chain relationships}

The issue of relationships within the construction supply chain was commonly expressed by participants. Most respondents admitted that there exist abrasive relationships between their firms and at least one of their internal and external stakeholders. The following comment from an operations manager reflects the widely shared feelings on this issue:

Relationships are problematic as there is a constant war between our firm and its suppliers as well as other stakeholders such as government and competing firms. Even internally, operations, buyers and strategic sourcing do not really work together, and this affects the operations of the firm. Without a firm structure anything we do is hitting a brick wall. I think half of strategic sourcing's efforts are wasted as buyers ignore recommendations. (P11, Male, 44 years)

A regional buyer lamented the inadequacy of both planning and supply relationship management:

Lack of planning is a huge constraint and the lack of supplier relationship management programs further contributes to losses. We continue to lose good suppliers and customers who are not happy with our services. (P7, Female, 39 years)

In addition, one senior manager mentioned the following three questions as topical issues that construction firms have to contend with: (1) How to organise the work among supply chain members? (2) How to achieve and maintain cooperation among these firms? (3) How to coordinate process execution among people from different firms that are autonomous. It was acknowledged that these three questions hold the key to supply chain relationships in the construction industry. As mentioned by Barratt (2010), the main tenacity of the construction supply chain is to coordinate actions of people and different organisations. This includes the flow of information that is intended to create a common context among people for mutual understanding. The flow of information also provides the economic stimulus for the firms to take part in the exchanges that are essential for conveying value to the client. However, misunderstandings or cases of clear breaches between one or more partners often emerge. For instance, the South African construction industry is highly competitive and often there is a reluctance to collaborate and share information with other stakeholders (Windapo \& Cattel 2013). At times, dissatisfied clients tend to switch to other firms that are competitors to the firm they are moving away from, further upsetting the relationships between the involved firms (Forgues \& Koskela 2009; Jiang, Henneberg \& Naude 2011). Some suppliers often battle to 
meet the competing needs of rival firms, which further exacerbates dysfunctional relationships between supply chain partners (Mbande 2010). Such caustic relationships naturally lead to the lack of proper cooperation or poor coordination or even to the loss of competitiveness by the entire supply chain.

\section{Structure of the construction industry}

There was an almost unanimous view from participants that the structure of the construction industry acted as a major impediment to the implementation of supply chain management. Issues raised include the fragmented nature of the industry, fixation to the same ways of running the firms, the lack of new ideas and the lack of strategic thinking. These sentiments were indicated by a senior plant and assets executive:

The industry is fragmented and most firms experience difficulties with internal silos. It is an industry steeped in a specific mind-set and with people constantly moving within the same industry but to different firms, the same entrenched cultures are transferred from one firm to the next. They also have a tendency to headhunt from within the same major players, which means that outsiders from construction find it difficult to enter this industry. (P15, Male, 63 years)

A senior buyer provided further evidence of the lack of new ideas within the industry:

The industry is characterised by the same key staff moving from one firm to the next - no new blood, hence new thinking is not happening on a regular basis. My view is that they need to bring people from outside of the industry in order to effectively fix it. (P14, Female, 37 years)

In addition, one of the procurement analysts highlighted that the construction firms have not adopted world-class business practices and principles and appeared to be disorganised, haphazard, and followed outdated structures that are not linked to strategy, leading to a lack of competitiveness. Also noted by one of the senior buyers was the view that the industry is unstructured and lagging behind in terms of strategic thinking and direction when compared to other industries. The logistics manager who participated in the study further indicated that nothing had fundamentally changed in the construction industry in South Africa in the past two decades, making firms to resemble family-owned businesses. Participants further lamented that conditions in the South African construction industry remain difficult and less prosperous. These responses portray a picture of disillusionment with the present condition of the construction industry in South Africa.

The nature of the industry presents a number of issues, ranging from the absence of effective systems and policies to haphazard methods of operating. The failure to change the existing culture, high inter-firm labour mobility as well as stagnation for a long time seem to be entrenched in the industry. The findings further demonstrate that most of the firms are more concerned with financial success at the expense of prudent business practices. Still, most of the bottlenecks within the industry seem to affect all departments and project processes and are dependent on both group as well as individual efforts. Chihuri and Pretorius (2010) pinpoint that understanding the prospects of the South African construction industry remains extremely difficult because many of the indicators show that there are many complex challenges. Although it is commendable that several firms have reported improved margins in the past few years, it could be argued that these improved margins are a result of forced restructuring in order to improve internal efficiencies (Antony 2013). Magoro and Brynard (2010) also suggest that the industry experiences high costs of materials, fraudulent practices and kickbacks and fluctuations in material prices that elevate the costs of construction. Furthermore, the majority of construction firms associate with one another at specific stages but this has been associated with collusion practices instead (Lam \& Wong 2011). Likewise, it has to be noted that most construction firms do not have the capacity to deal with the increasing number of firms and subsidiaries in different locations and the lack of synergies is clearly visible (Windapo \& Cattell 2013). Therefore, it is necessary to direct efforts towards accomplishing a visible and integrated supply chain structure in this industry, if these persistent challenges are to be overcome.

\section{Limitations and suggestions for future research}

This study was limited through its heavy reliance on the qualitative approach, which has its own inherent weaknesses. This provides room to conduct similar studies using a quantitative approach, which uses more objective criteria that may serve to validate current results. The current study was further limited in that it exclusively directed its attention to the construction industry. As a remedy, further studies with a similar focus could be conducted in other industry segments falling under key economic sectors such as manufacturing, mining, agriculture and retail. The findings of such studies could then be used as a reference point in enhancing the success of supply chain management initiatives in these industries. Also, given that the present study was restricted to bottlenecks only, future studies could include supply chain risks (exposures) facing the construction industry because they too are equally important. This could lead to further findings, which could not be covered in this study. In addition, other studies could investigate the influence of supply chain bottlenecks identified in this study on supply chain performance in the construction industry. This could assist supply chain professionals in their diagnoses of supply chain performance-related challenges in the construction industry. It is also notable that participants were senior managers and they mentioned several issues pertaining to behaviours and practices of lower level employees in the construction industry. Future studies could focus on the views of lower level employees because it is most ideal for such groups to speak for themselves. 


\section{Conclusion and recommendations}

The aim of this study was to investigate supply chain bottlenecks facing the construction industry in South Africa. Similar to other industries, construction performs an indispensable role in the economy and is a noteworthy contributor to economic development in South Africa. The construction industry in South Africa is quite complex, consisting of numerous stakeholders and is characterised by stiff competition from all sizes of firms. There is also no doubt that supply chain management is applicable to construction and offers general guidelines that can be used to analyse, reengineer, coordinate and constantly improve virtually the complete construction supply chain, thereby resolving basic problems experienced in the industry. Through structured, in-depth interviews with senior managers in that industry, five themes, namely skills and qualifications, procurement practices and systems, supply chain integration, supply chain relationships and structure of the construction industry were identified as the major bottlenecks constraining supply chain management in this study. However, both awareness and implementation of supply chain management in the construction industry in South Africa remains limited, which creates opportunities for further improvement for research in this area if the full potential of the industry is to be realised.

Based on the findings of this study, several recommendations are put forward to either eradicate the identified bottlenecks or minimise their effects in the construction industry. To improve the competency of professionals in the industry, training and development of both managers and employees is necessary. In particular, the training should enable these groups to embrace the use of best practices in supply chain management as tools for both decision making and problem solving. Examples of training and development courses that could be undertaken include the Production and Inventory Management Certification, International Certificate in Risk Management, Certified Supply Chain Professional, Certified Professional Forecaster and the Certified Demand Driven Planner programme, among others. Further development and amendment of policies and processes is necessary to update currently existing ones, followed by stringent compliance monitoring and consequence management, which could lead to better procurement practices. This, for instance, may be applied to specifying the different roles of managers and buyers in procurement. Relationships within the construction industry could be improved through stakeholder relationship management programmes. These include supplier relationship management, supplier development, customer relationship management and improved communication practices within the industry. For example, when a construction industry firm discovers that a strategic supplier is struggling to meet their material needs, the firm should seek out ways of assisting the supplier in order to restore normal supplies. This is preferable to the costly practice of switching from one supplier to the next because the replacement supplier can experience the same, if not more intense challenges. Likewise, specific personnel within the supply chain department should be allocated the responsibility of managing relationships with suppliers as an operational activity. In the marketing department, there should be personnel dedicated to managing relationships with key customers in order to retain their loyalty. To curtail dysfunctional relationships with competitors, firms should enter into joint projects with their competitors so that they can complement each other's competencies and form longlasting collaborative partnerships. Room also exists for horizontal integration, which can be achieved by either merging with competing firms or buying out some of the more threatening competitors.

Change management programmes are also necessary throughout the construction industry to counteract any dysfunctional cultures currently dominating the industry. To achieve this, various change models can be used, such as John Kotter's Eight-Step Change Management Process, the Change Management Foundation and Model and the Deming Cycle of Plan-Do-Check-Act (Anderson 2013; Little 2014). Acceptance of change within the construction industry may lead to the recruitment of new professionals who can bring new ideas from other industries. To minimise costs, firms should increase their budgetary allocations to allow for 'hidden taxes or costs' in South Africa. This is in line with the suggestion by Modares and Sepehri (2009) that firms in the construction industry can realise profits by limiting overhead costs, raising labour productivity and/ or rationalising site organisation. Adequate planning at the early stages of any construction project is essential and should be implemented to minimise delays and cost overruns (Nordin et al. 2010). Moreover, sustained growth and development of the construction industry could be achieved through the adoption of state-of-the-art technologies and systems for use within firms as well as at construction sites. For example, the addition of automated equipment in construction could result in faster project completion and better quality outputs while minimising labour costs (Wibowo \& Sholeh 2015).

More construction firms should integrate vertically in the industry by moving to control input suppliers of essential input such as bricks, cement, tiles, paint and glass, among others. Such integration may be facilitated through early procurement by subcontractors; subcontractor selection, which is not based solely on lowest price; compensation including joint profit sharing; suitable risk allocation and the use of collaborative tools and approaches (Flynn, Huo \& Zhao 2010; Kim 2013). It would further be wise for firms to exercise caution always, accept greater levels of risk and purchase additional insurance to cover possible losses when undertaking construction projects (Mosenogi 2014). Such due diligence is particularly important in South Africa, where the volatility of the operational environment has increased as a result of various factors within the political, economic, social, technological and ecological landscape. Still, cooperation with government policies and standards remains essential to avert the stiff penalties that can be imposed by government when breaches are detected. 


\section{Acknowledgements}

The authors thank those companies in the construction industry in South Africa that participated in this research.

\section{Competing interests}

The authors declare that they have no financial or personal relationships that may have inappropriately influenced them in writing this article.

\section{Authors' contributions}

P.P. was responsible for conducting the literature review and collecting the data. C.M. was responsible for compiling the sections of the article.

\section{References}

Albaloushi, H. \& Skitmore, M., 2008, 'Supply chain management in the UAE construction industry', International Journal of Construction Management 8(1) 53-71. https://doi.org/10.1080/15623599.2008.10773108

Aloini, D., Riccardo, D., Valeria, M. \& Simone, P., 2012, 'Supply chain management: A review of implementation risks in the construction industry', Business Process Management Journal 18(5), 735-761. https://doi.org/10.1108/14637151211270135

Alves, T.C.L. \& Tsao, C.C.Y., 2007, 'Lean construction - 2000 to 2006', Lean Construction Journal 3(1), 46-70.

Anderson, J., 2013, The lean change method: Managing agile organizational transformation using Kanban, Kotter, and lean startup thinking, Create Space Independent Publishing Platform, viewed 12 January 2017, from https:// business901.com/blog1/using-kanban-kotter-lean-startup-thinking/

Antony, A.M., 2013, 'The legal regulation of construction procurement in South Africa', Masters dissertation, Faculty of Law, Stellenbosch University, South Africa.

Arantes, A., Ferreira, L.M.D.F. \& Costa, A.A., 2015, 'Is the construction industry aware of supply chain management? The Portuguese contractors' perspective', Supply Chain Management: An International Journal 20(4), 404-414. https://doi. org/10.1108/SCM-06-2014-0207

Bankvall, L., Bygballe, L.E., Dubois, A. \& Jahre, A., 2010, 'Interdependence in supply chains and projects in construction', Supply Chain Management: An International Journal 15(5), 385-393. https://doi.org/10.1108/13598541011068314

Barnes, J. \& Liao, Y., 2012, 'The effect of individual, network, and collaborative competencies on the supply chain management system', International Journal of competencies on the supply chain management system,' International Journal of
Production Economics 140(2), 888-899. https://doi.org/10.1016/j.ijpe.2012.07.010

Barratt, M., 2010, 'Exploring the experiences of collaborative planning initiatives', International Journal of Physical Distribution and Logistics Management 33(2), 32-38.

Beer, M. \& Noria, N., 2000, Breaking the code of change, Harvard Business School Press, Boston, MA

Bowen, P., Pearl, R. \& Akintoye, A., 2007, 'Professional ethics in the South African construction industry', Building Research and Information 35(2), 189-205. https://doi.org/10.1080/09613210600980267

Chihuri, S. \& Pretorius, L., 2010, 'Managing risk for success in a South African engineering and construction project environment', The South African Journal of Industrial Engineering 21(2), 63-77.

Chun, S., Hwang, H.J. \& Byun, Y., 2015, 'Green supply chain management in the construction industry: Case of Korean construction companies', Procedia-Social and Behavioral Sciences 186, 507-512. https://doi.org/10.1016/j.sbspro.2015.04.192

Construction Industry Development Board, 2011, Construction quality in South Africa; A client perspective: A discussion document, CIDB, Pretoria.

Construction Industry Development Board, 2016, Construction monitor: Supply and demand, viewed 13 April 2017, from www.cidb.org.za/publications/... Construction $\% 20$ Monitor\%20-\%20April\%202016.pdf

Corbin, J. \& Strauss, A., 2008, Basics of qualitative research, 3rd edn., Sage, Thousand Oaks, CA.

Cresswell, J.W. \& Plano Clark, V.L., 2011, Designing and conducting mixed method research, 2nd edn., Sage, Thousand Oaks, CA.

Creswell, J.W. \& Poth, C.N., 2013, Qualitative inquiry and research design - Choosing among five approaches, Sage, Thousand Oaks, CA.

Dainty, A.R.J., Millett, S.J. \& Briscoe, G.H., 2001, 'New perspectives on construction supply chain integration', Supply Chain Management: An International Journal 6(4), 163-173.

Department of Higher Education and Training, 2016, List of occupations in high demand 2015, Government Gazette, 19 January 2016, viewed 20 March 2017 from demand 2015, Government Gazette, 19 January 2016, viewed 20 March 2017 from $39604, \% 2019 \% 20 J$ January $\% 202016 . \% 20$ List $\% 20$ of $\% 200$ ccupations $\% 20$ in $\% 20$ High\%20Demand\%202015.pdf
Doloi, H., 2013, 'Empirical analysis of traditional contracting and relationship agreements for procuring partners in construction projects', Journal of Management in Engineering 29(3), 224-235, https://doi.org/10.1061/(ASCE) ME.1943-5479.0000141

Eddie, W., Cheng, H.L., Love, P.E. \& Irani, Z., 2001, 'An e-business model to support supply chain activities in construction', Logistics Information Management 14(1/2), 68-78. https://doi.org/10.1108/09576050110363239

Emuze, F.A., 2009, 'The impact of construction supply chain management on value on projects', Masters dissertation, Faculty of Engineering, Nelson Mandela Metropolitan University, South Africa.

Emuze, F.A. \& Smallwood, J., 2013, 'How can supply chain management proliferate in South African construction?', in S.D. Smith \& D.D. Ahiaga-Dagbui (eds.), Proceedings of the 29th Annual ARCOM Conference, Association of Researchers in Construction Management, Reading, UK, September 2-4, pp. 513-522.

Engineering Council of South Africa 2015. Annual Report 2014/2015, viewed 12 January 2017, from https://www.ecsa.co.za/about/pdfs/Ecsa_Annual_Report_2015.pdf

Eriksson, P.E., 2010, 'Improving construction supply chain collaboration and International Journal 15(5), 394-403. https://doi.org/10.1108/13598541011068323

Esper, T.L., Defee, C.C. \& Mentzer, J.T., 2010, 'A framework of supply chain orientation', International Journal of Logistics Management 21(2), 161-179. https://doi. org/10.1108/09574091011071906

Esser, I. \& Decker, A., 2008, 'The dynamics of corporate governance in South Africa: Broad based black economic empowerment and the enhancement of good corporate governance principles', Journal of International Commercial Law and Technology 3(3), 157-169.

Fayazbakhsh, K., Sepehri, M. \& Razzazi, M., 2013, 'Supply chain coordination with flow networks', South African Journal of Business Management 17(23), 17-31.

Finfgeld-Connett, D, 2010, 'Generalizability and transferability of meta-synthesis research findings', Journal of Advanced Nursing 66, 246-254. https://doi. org $/ 10.1111 / \mathrm{j} .1365-2648.2009 .05250 . x$

Forgues, D. \& Koskela, L., 2009, 'The influence of a collaborative procurement approach using integrated design in construction on project team performance, International Journal of Managing Projects in Business 2(3), 370-385. https://doi. org/10.1108/17538370910971036

Flynn, B.B., Huo, B. \& Zhao, X., 2010, 'The impact of supply chain integration on performance: A contingency and configuration approach', Journal of Operation Management 28(1), 58-71. https://doi.org/10.1016/j.jom.2009.06.001

Gigaba, M., 2014, Construction sector faces many challenges, South African News Agency, viewed 20 March 2017, from http://www.sanews.gov.za/south-africa/ construction-sector-faces-many-challenges-gigaba

Gligor, D.M. \& Holcomb, M.C., 2012, 'Antecedents and consequences of supply chain agility: Establishing the link to firm performance', Journal of Business Logistics 33(4), 295-309. https://doi.org/10.1111/jbl.12003

Gohari, A., 2014, 'Supply chain management in the construction industry', Advances in Management 7(8), 15-24.

Hugo, W.M.J., Badenhorst-Weiss, J.A. \& Van Bilton, E.H.B., 2004, Supply chain management: Logistics in perspective, Van Schaik, Pretoria.

Hyll, H., 2005, 'Logistical principles in construction supply chains', Licentiate thesis, Lund University, Sweden, viewed 28 May 2017, from http://portal.research.lu.se/portal/ University, Sweden, viewed 28 May 2017, from http://portal.research.lu.se/portal/ en/publications/logistical-principles-in

Ibem, E.O. \& Laryea, S., 2015, 'E-procurement use in the South African construction industry', Journal of Information Technology in Construction 20, 364-384.

Jansen, H., 2010, 'The logic of qualitative survey research and its position in the field of social research methods', Forum Qualitative Social Research 11(2), 1-21.

Jiang, Z., Henneberg, S.C. \& Naudé, P., 2011, 'Supplier relationship management in the construction industry: The effects of trust and dependence', Journal of Business \& Industrial Marketing 27(1), 3-15. https://doi.org/10.1108/08858621211188920

Khalfan, M., McDermott, P. \& Cooper, R., 2004, 'Integrating the supply chain within construction industry' in $\mathrm{F}$. Khosrowshahi (ed.), 20th Annual ARCOM Conference, construction industry', in F. Khosrowshahi (ed.), 20th Annual ARCOM Conference, Construction Management, pp. 897-904.

Khalfan, M.M.A. \& McDermott, P., 2006, 'Innovating for supply chain integration within construction', Journal of Construction Innovation 6, 143-157. https://doi. org/10.1108/14714170610710695

Khalfan, M.M.A., McDermott, P. \& Swan, W., 2007, 'Building trust in construction projects', Supply Chain Management: An International Journal 12(6), 385-391.

Khumalo, J., Mashiane, J. \& Roberts, S., 2014, 'Harm and overcharge in the South African precast concrete products cartel', Journal of Competition Law and Economics 10(3), 621-646. https://doi.org/10.1093/joclec/nhu005

Kim, D.Y., 2013, 'Relationship between supply chain integration and performance', Operations Management Research 6(1-2), 74-90. https://doi.org/10.1007/ s12063-013-0079-0

Kozlenkova, I.V., Hult, G.T.M., Lund, D.J., Mena, J.A. \& Kekec, P., 2015, 'The role of marketing channels in supply chain management', Journal of Retailing 91(4), 586-609. https://doi.org/10.1016/j.jretai.2015.03.003

Lam, P.T.I. \& Wong, W.H., 2011, 'A comparative study of buildability perspectives between clients, consultants and contractors', Construction Innovation 11(3), 305-320. https://doi.org/10.1108/14714171111149025

Lee, N. \& Lings, I., 2008, Doing business research: A guide to theory and practice, Sage, Thousand Oaks, CA.

Lincoln, Y.S., Lynham, S.A. \& Guba, E.G., 2011, Paradigmatic controversies, contradictions, and emerging confluences, revisited, The Sage Handbook of Qualitative Research, Sage, Thousand Oaks, CA. 
Linhares, A., 2009, 'Theory of constraints and the combinatorial complexity of the product-mix decision', International Journal of Production Economics 121(1), 121-129. https://doi.org/10.1016/j.ijpe.2009.04.023

Little, J., 2014, Lean change management: Innovative practices for managing organizational change, Happy Melly Express, viewed 15 January 2017, from https://leanpub.com/leanchange

Lönngren, H.M., Rosenkranz, C. \& Kolbe, H., 2010, 'Aggregated construction supply chains: Success factors in implementation of strategic partnerships', Supply Chain Management: An International Journal 15(5), 404-411. https://doi.org/10.1108/ 13598541011068297

Mafini, C. \& Dhurup, M., 2015, 'Drivers of customer loyalty in South African retail stores', Journal of Applied Business Research 31(4), 1295-1310. https://doi. org/10.19030/jabr.v31i4.9317

Mafini, C., Loury-Okoumba, W.V. \& Pooe, D., 2016, 'Interrogating antecedents to SME supplier performance in a developing country', Southern African Business Review 20, 259-285.

Magoro, M.J. \& Brynard, P.A., 2010, 'Difficulties associated with the implementation of the preferential procurement policy in conjunction with a low-cost housing programme: A South African contextualization', Politeia 29(3), 4-23.

Mason, M., 2010, 'Sample size and saturation in PhD studies using qualitative interviews', Forum: Qualitative Social Research 11(3), viewed 28 February 2017 from http://www.qualitative-research.net/index.php/fqs/article/view/1428/3027

Mbande, C., 2010, 'Overcoming construction constraints through infrastructure delivery', in Proceedings: The Association of Schools of Construction of Southern Africa (ASOCSA), Fifth Built Environment Conference. Durban, South Africa, July 18-20, pp 213-232.

McDermott, P. \& Khalfan, M.A., 2012, 'Achieving supply chain integration within construction industry', The Australian Journal of Construction Economia and Building 16(2), 44-52. https://doi.org/10.5130/ajceb.v6i2.2983

Modares, A. \& Sepehri, M., 2009, 'Development of integrated system for distribution planning in supply chain', South African Journal of Business Management 40(4), 13-23.

Moe, C.K. \& Päivärinta, T., 2013, 'Challenges in information systems procurement in the public sector', Electronic Journal of e-Government 11(2), 308-323.

Mosenogi, J.M., 2014, 'An impact analysis of construction sector on economic growth and household income in South Africa', Masters dissertation, Mafikeng Campus, North West University, South Africa, viewed 28 May 2017, from https://dspace. nwu.ac.za/handle/10394/15654?show=full

Motsetse, M.J., 2015, 'The role of government in developing sustainable SMEs in the construction sector in the Free State province', Masters dissertation, Busines School, University of the Free State, Bloemfontein, South Africa.

Nene, N., 2015, 2015 Budget Speech, South African National Treasury, viewed 10 March 2017, from www.treasury.gov.za/documents/national\%20budget/2015/ March 2017, from
speech/speech.pdf

Nordin, F., Oberg, C., Kollberg, B. \& Nord, T., 2010, 'Building a new supply chain position< An exploratory case study within the construction industry', Construction Management and Economics 28, 1071-1083. https://doi.org/10.1080/01446193. 2010.494680

Ofori, G., 2013, 'Construction in developing countries', Construction Management and Economics 25(1), 1-19. https://doi.org/10.1080/01446190601114134

Ojo, E., Mbowa, C. \& Akinlabi, E.T., 2014, 'Barriers in implementing green supply chain management in construction industry', in Proceedings of the 2014 International Conference on Industrial Engineering and Operations Management, Bali, Indonesia, January 7-9, pp. 1974-1981.

Olson, F., 2000, 'Supply chain management in the construction industry', Licentiate thesis, Lund University, Sweden, viewed 28 May 2017, from http://portal.research. lu.se/portal/en/publications/supply-chain-management-in-the-constructionindustry(5952a901-c538-4155-8bb5-a1e850262e55)/export.html\#export

Padgett, D., 2016, Qualitative methods in social work research, 3rd edn., Sage, Los Angeles, CA.

Paulus, T.M. \& Lester, J.N., 2016, 'ATLAS.ti for conversation and discourse analysis studies', International Journal of Social Research Methodology 19(4), 405-428. https://doi.org/10.1080/13645579.2015.1021949

Peat, M. \& Anna, M., 2007, Supply chain management in construction industry viewed 03 September 2014, from http://www.ice.org.uk/Information-resources/ Document-Library/Supply-chain-management-in-constructionindustry

Perera, S., Davis, S. \& Marosszeky, M., 2009, 'A two dimensional view of the supply chain on construction projects', in Proceedings of the 17th Annual Conference of the International Group for Lean Construction, Taipei, 2009, Taipei, Taiwan, July 15-17, pp. 127-136.

Prajogo, D. \& Olhager, J., 2012, 'Supply chain integration and performance: The effects of long-term relationships, information technology and sharing, and logistics
integration', International Journal of Production Economics 135(1), 514-522. integration', International Journal of Product
https://doi.org/10.1016/j.ijpe.2011.09.001

PricewaterhouseCoopers, 2014, Highlighting trends in the South African Construction Industry December 2013, 1st edn., South Africa Construction viewed 20 March 2017, from https://www.pwc.co.za/en/assets/pdf/saconstruction-december-2013.pdf

PricewaterhouseCoopers, 2017, SA's emerging companies face a multitude of challenges-but there is room for improvement: PwC report, viewed 21 March 2017, from http://www.pwc.co.za/en/press-room/sa_s-emerging-firms-face-amultitude-of-challenges--but-ther.html

Pryke, S., 2009, Construction supply chain management: Concepts and case studies, Wiley-Blackwell, Oxford.

Report Buyer, 2016, Construction in South Africa-Key trends and opportunities to 2020 viewed 03 March 2017, from https://www.reportbuyer.com/product/1634379/ construction-in-south-africa-key-trends-and-opportunities-to-2020.html
Rust, F.C., Botha, C., Van Wyk, L., Steyn, W., Du Plessis, C., Landman, K. et al., 2013, South African construction industry technology foresight study: Summary report South African construction industry technology foresight
of desktop study, CSIR Technical Report, CSIR, Pretoria.

Saldaña, J., 2011, The coding manual for qualitative researchers, Sage, Thousand Oaks, CA.

Schreier M., 2012, Qualitative content analysis in practice, Sage, Thousand Oaks, CA.

Segerstedt, A. \& Olofsson, T., 2010, 'Supply chains in the construction industry', Supply Chain Management: An International Journal 15(5), 347-353. https://doi. org/10.1108/13598541011068260

Shakantu, W.M.W., Tookey, J., Muya, M. \& Bowen, P., 2007, 'Beyond Egan's supply chain management: Advancing the role of logistics in the South African construction industry', Acta Structilia 14(1), 93-115.

Shunmugam, S. \& Rwelamila, P.D., 2014, 'An evaluation of the status of risk management in South African construction projects', Conference paper presented at the Project Management South Africa (PMSA) Conference 2014, Johannesburg, South Africa, 27 September to 01 October, viewed 05 April 2017 from http://c. South Africa, 27 September to 01 October, viewed 05 April 2017 from http://c.
ymcdn.com/sites/www.projectmanagement.org.za/resource/resmgr/Academic ymcdn.com/sites/www.projectmanagement.org.za/r

Simatupang, T.M. \& Sridharan, R., 2012, 'The collaborative supply chain', Internationa Journal of Logistics Management 13(1), 15-30. https://doi.org/10.1108/09574 Journal of Logistic

Sinkovics, R.R. \& Alfoldi, E.A., 2012, 'Progressive focusing and trustworthiness in qualitative research: The enabling role of computer-assisted qualitative data analysis software (CAQDAS)', Management International Review 52(6), 817-845. $\mathrm{https}: / /$ doi.org/10.1007/s11575-012-0140-5

Smallwood, J.J. \& Emuze, F.A., 2012, 'Status of quality in South African construction The case of a general contractor', in Proceedings of the 6th International Conference and Workshop on the Built Environment in Developing Countries (ICBEDC-2012), December 4-5, Adelaide, Australia, pp. 113-124.

Sohail, M. \& Cavill, S., 2008, 'Accountability to prevent corruption in construction projects', Journal of Construction Engineering and Management 134(9), 729-738. https://doi.org/10.1061/(ASCE)0733-9364(2008)134:9(729)

South African Construction Industry Status Report, 2013, Synthesis review on the South African construction industry and its development, viewed 04 March 2014 from http://www.cidb.org.za/documents/kc/cidb_publications/ind_reps_other/ ind_reps_status_report_2004.pdf

South African Federation of Civil Engineering Contractors (SAFCEC), 2014, Annua report 2013-2014, viewed 13 February 2017, from http://www.c.ymcdn.com/ sites/safcec.site-ym.com/.../SAFCECAnnualReport_2013-14_W.pdf

Statistics South Africa, 2014, Quarterly employment statistics, viewed 04 April 2017 from http://www.statssa.gov.za/publications/P0277/P0277June2014.pdf

Statistics South Africa, 2016, Manufacturing and construction industries report 2016, viewed 05 April 2017, from http://www.statssa.gov.za/?page_id=624

Stevenson, W.J., 2012, Operations management, 11th edn., McGraw-Hill, Boston.

Tennant, S. \& Fernie, S., 2014, 'Theory to practice: A typology of supply chain management in construction', International Journal of Construction Management 14(1), 56-66. https://doi.org/10.1080/15623599.2013.875268

Titus, S. \& Bröchner, J., 2005, 'Managing information flow in construction supply chains', Construction Innovation 5(2), 71-82. https://doi.org/10.1108/14714170510815186

Tran, Q., Huang, D., Liu, B. \& Ekran, H.M., 2011, 'A construction enterprise's readiness leve in implementing e- procurement: A system engineering assessment model', Systems Engineering Procedia 2, 131-141. https://doi.org/10.1016/j.sepro.2011.10.016

Van Weele, A.J., 2014, Purchasing and supply chain management: Analysis, strategy, planning and practice, 6th edn., Thomson Learning, Melbourne, Australia.

Venkataraman, R.R. \& Pinto, J.K., 2008, Supply chain management, in cost and value management in projects, Wiley, Hoboken, NJ.

Voordijk, H., Meijboom, B. \& De Haan, J., 2006, 'Modularity in supply chains: A multiple case study in the construction industry', International Journal of Operations and Production Management 26(6), 600-618. https://doi.org/ 10.1108/01443570610666966

Vrijhoef, R. \& Koskela, L., 2000, 'The four roles of supply chain management in construction', European Journal of Purchasing and Supply Management 6(3/4), 169-178.

Vrijhoef, R. \& Voordijk, R., 2003, 'Improving supply chain management in construction: What can be learned from the aerospace industry?', in D.J. Greenwood (ed.) Association of Researchers in Construction Management: 19th Annual ARCOM Conference, vol. 2, September 3-5, University of Brighton, pp. 251-261.

Wibowo, M.A. \& Sholeh, M.N., 2015, 'The analysis of supply chain performance measurement at a construction project', Procedia Engineering 125, 25-31. https://doi.org/10.1016/j.proeng.2015.11.005

Wieland, A. \& Handfield, R.B., 2013, 'The socially responsible supply chain: An imperative for global corporations', Supply Chain Management Review 17(5), 22-29.

Windapo, A.O., 2016, 'Skilled labour supply in the South African construction industry: The nexus between certification, quality of work output and shortages', SA Journal of Human Resource Management/SA Tydskrif vir Menslikehulpbronbestuur 14(1), 1-8.

Windapo, A.O. \& Cattell, K., 2013, 'The South African construction industry: Perceptions of key challenges facing its performance, development and growth', Journal of Construction in Developing Countries 18(2), 65-79.

Wu, M.Y. \& Weng, Y.C., 2010, 'A study of supplier selection factors for high-tech industries in the supply chain', Total Quality Management 21(4), 319-403. https:// doi.org/10.1080/14783361003606662

Zaghoul, R. \& Hartman, F., 2013, 'Construction contracts: The cost of mistrust', International Journal of Project Management 33, 243-257. 